\title{
Leaf area and growth of Chilean radiata pine plantations after thinning across a water stress gradient
}

\author{
Hebert Ojeda ${ }^{1,2^{*}}$ (D), Rafael A. Rubilar ${ }^{1}{\text { Cristian } \text { Montes }^{3} \text {, Jorge Cancino }}^{1}$ and Miguel Espinosa ${ }^{1}$
}

\begin{abstract}
Background: Pinus radiata D.Don has been established in a wide range of soils and climatic conditions, showing high variability in both leaf area and volume productivity. Previous research has shown that plantation yield is affected by water availability, but the majority of this work has been done in unthinned stands and provided little insight on the effect of water availability on the productivity of thinned plantations. In order to improve forest productivity for plantations under a climate change scenario, we must understand the effect of plantation management, including thinning on the relationships among available water, leaf area index, and productivity. The aim of this work is to evaluate the effect of site water availability on the leaf area production and consequent volume growth in thinned radiata pine plantations over a water availability gradient.

Methods: The effect of site available water on leaf area production and consequent volume growth in thinned Pinus radiata plantations over a water availability gradient across five sites in central and southern-central Chile was determined.

Results: Regression analysis revealed water deficit to be related to both leaf area index and volume growth accounting for 77 and $78 \%$ of the variation respectively. Eighty-one percent of the variation in volume growth was explained by the leaf area index. Results showed a growth efficiency of $5 \mathrm{~m}^{3} \mathrm{ha}^{-1}$ per unit of leaf area index.

Conclusions: Strong linear positive relationships between site water availability, leaf area, and stand growth after thinning found in this research suggest that water is the key factor controlling current productivity of radiata pine plantations across sites. A simple and robust water index that is well correlated with leaf area and stand annual volume growth allows for the construction of a simple predictive model that may support management decisions for radiata pine plantations.
\end{abstract}

Keywords: Growth efficiency, Leaf area index, Pinus radiata, Productivity, Water deficit

\section{Background}

Radiata pine (Pinus radiata D.Don) is the most widely distributed of commercial pine species. There are more than 4 million ha planted with radiata pine in the world, with the largest areas in New Zealand (1.7 million ha), Chile (1.5 million ha), Australia (0.77 million ha), Spain (0.29 million ha), and South Africa (57,000 ha) (Mead 2013; Ministry for Primary Industries, New Zealand Forest Owners Association Inc. and New Zealand Farm Forestry Association 2016).

\footnotetext{
* Correspondence: hebertojeda@udec.cl; hojeda@arauco.cl

${ }^{1}$ Facultad de Ciencias Forestales, Universidad de Concepción, Victoria 631, Barrio Universitario, Concepción, Chile

${ }^{2}$ Bioforest S.A., Camino a Coronel km 15 s/n, Coronel, Chile

Full list of author information is available at the end of the article
}

The productivity of this species is strongly influenced by site conditions (Grey 1989) and varies more than twofold from 12 to $34 \mathrm{~m}^{3} \mathrm{ha}^{-1}$ year in commercial plantations (Del Lungo and Carle 2006; Álvarez et al. 2013). Early work relating the growth of radiata pine to site and climatic factors showed that rainfall and its seasonal distribution, effective soil depth, total nitrogen, available phosphorous, and temperature all affected productivity (Jackson and Gifford 1974).

Plantation available water, determined by rainfall and soil water holding capacity, is the main determinant of both actual and potential radiata pine productivity in New Zealand (Jackson and Gifford 1974; Hunter and Gibson 1984), Australia (Czarnowski et al. 1971), South Africa 
(Grey 1989), and Chile (Gerding and Schlatter 1995; Flores and Allen 2004). Álvarez et al. (2013) showed that both water availability and evaporative demand were important limits to the growth of the species in Chile.

Forest, including plantation, productivity is positively correlated with leaf area index (LAI) (Jarvis and Leverenz 1983; Linder 1987; Vose and Allen 1988; Álvarez et al. 2013) which determines the rate of energy and gas exchange $\left(\mathrm{CO}_{2}, \mathrm{O}_{2}\right.$, and $\left.\mathrm{H}_{2} \mathrm{O}\right)$ between the forest canopy and the atmosphere (Vose et al. 1994). The LAI is, in turn, affected by the supply of nutrients and water and by temperature (Battaglia et al. 1998; White et al. 2010).

In many situations, especially in plantations where nutrient supply is adequate, available water is the primary determinant of leaf area index and tree growth (Benecke 1980; Cromer et al. 1983; Linder et al. 1987; Raison et al. 1992; Albaugh et al. 1998; Benson et al. 1992; Rubilar et al. 2013). For instance, Rubilar et al. (2013) established a linear relation between LAI and stem growth in three stands of radiata pine, located in sites with different productivities, finding that the growth efficiency (slope of this relation) was affected by water availability of the sites. Similar relations between LAI and productivity have been found by other researchers (Gower et al. 1992; Albaugh et al. 1998; Guo and Gifford 2002). Strong correlations between LAI and water availability have been observed for a wide range of forest types and climatic conditions (Grier and Running 1977; Gholz 1982). However, little information is available on this important relationship for radiata pine plantations of intermediate ages and particularly for thinned stands.

In recent decades in Chile, climatic trends have reduced water availability and resulted in more erratic rainfall within years and more frequent and severe summer droughts; this has been associated with reduced forest growth (Neuenschwander 2010). It is anticipated that this trend of reduced rainfall in temperate and Mediterranean plantation zones will continue in the future (Mullan et al. 2005; Galindo and Samaniego 2010; Neuenschwander 2010; Kirschbaum et al. 2012). It is therefore important to quantify the effect of water availability on LAI and consequently stand growth. In order to improve forest productivity for plantations under a climate change scenario, we must understand the effect of plantation management, including thinning on the relationships among available water, LAI, and productivity.

The aim of this study was to evaluate the effect of site available water on leaf area production and consequent volume growth in thinned radiata pine plantations over a water availability gradient.

\section{Methods}

\section{Study area}

Five sites were selected in central and southern-central Chile between latitudes $35^{\circ} \mathrm{S}$ and $40^{\circ} 30^{\prime} \mathrm{S}$ (Fig. 1).
These sites represent a gradient of climate and soils with known differences in productivity (Table 1). In 2000 or 2001 , all sites were planted with radiata pine at an initial stocking of 1250 trees per hectare. Sites were labelled according to their average annual rainfall $(833 \mathrm{~mm}, P 800$; $1078 \mathrm{~mm}$, P1100; $1492 \mathrm{~mm}$, P1500; $1683 \mathrm{~mm}$, P1700; $1733 \mathrm{~mm}$, P1750). Within each site, four 0.36-ha plots were located on smooth hills with no drainage problems and no signs of fungi, insects, or nutritional deficits. Plot locations were selected to cover the range of local variation in productivity. All plots had pre-planting weed control as well as 2 years of competition release after planting. Stands were thinned down to 800 trees per ha at the time at either age 6 or 7 years. Trees were removed from all diameter classes. Buffers that were $15 \mathrm{~m}$ wide were set aside around each plot, leaving measured plots of 0.09 ha $(30 \times 30 \mathrm{~m})$, which each contained 72 trees.

\section{Tree foliage biomass}

At the time of thinning, foliage biomass was estimated on ten trees representing the diameter distribution for each stand. After, the diameter of tree stems, located at $1.3 \mathrm{~m}$ above the ground (DBH), was measured; the sample trees were cut at the ground line and divided into stem, leaves, and branches. Branch diameter and distance from the tree top were measured for all branches on each felled tree. Between 10 and 15 branches were selected from each tree to cover the range of branch diameters on the felled trees. Foliage and branch tissues were separated for each sampled branch and dried at $70{ }^{\circ} \mathrm{C}$ to a constant weight.

Regression was used to derive a relationship between foliage biomass from branch and both relative distance from the top and branch diameter as described by Rubilar et al. (2010). The resultant relationship (Eq. 1) was used to estimate foliage biomass for the other branches.

$$
\begin{aligned}
\ln \left(1000 \times Y_{i}+1\right)= & a+b \times \ln \left(\mathrm{BD}_{i}+1\right)+c \\
& \times\left(\mathrm{RDFT}^{2}+1\right)+\varepsilon_{i}
\end{aligned}
$$

where:

$Y_{i}$ is the foliage biomass $(\mathrm{g})$ at the $i$ th branch $\mathrm{BD}_{i}$ is branch diameter in $\mathrm{cm}$ at the $i$ th branch

$\mathrm{RDFT}_{i}$ is the relative distance of insertion of the branch from the top of the tree $(0.0-1.0)$ at the $i$ th branch

$\varepsilon_{i}$ is the error associated with the $i$ th branch

The total foliage biomass was then calculated as the sum of the values for all branches. Finally, a model was fitted between foliage biomass at the tree level and DBH for each site. The adjusted model (Eq. 2) has the following form: 


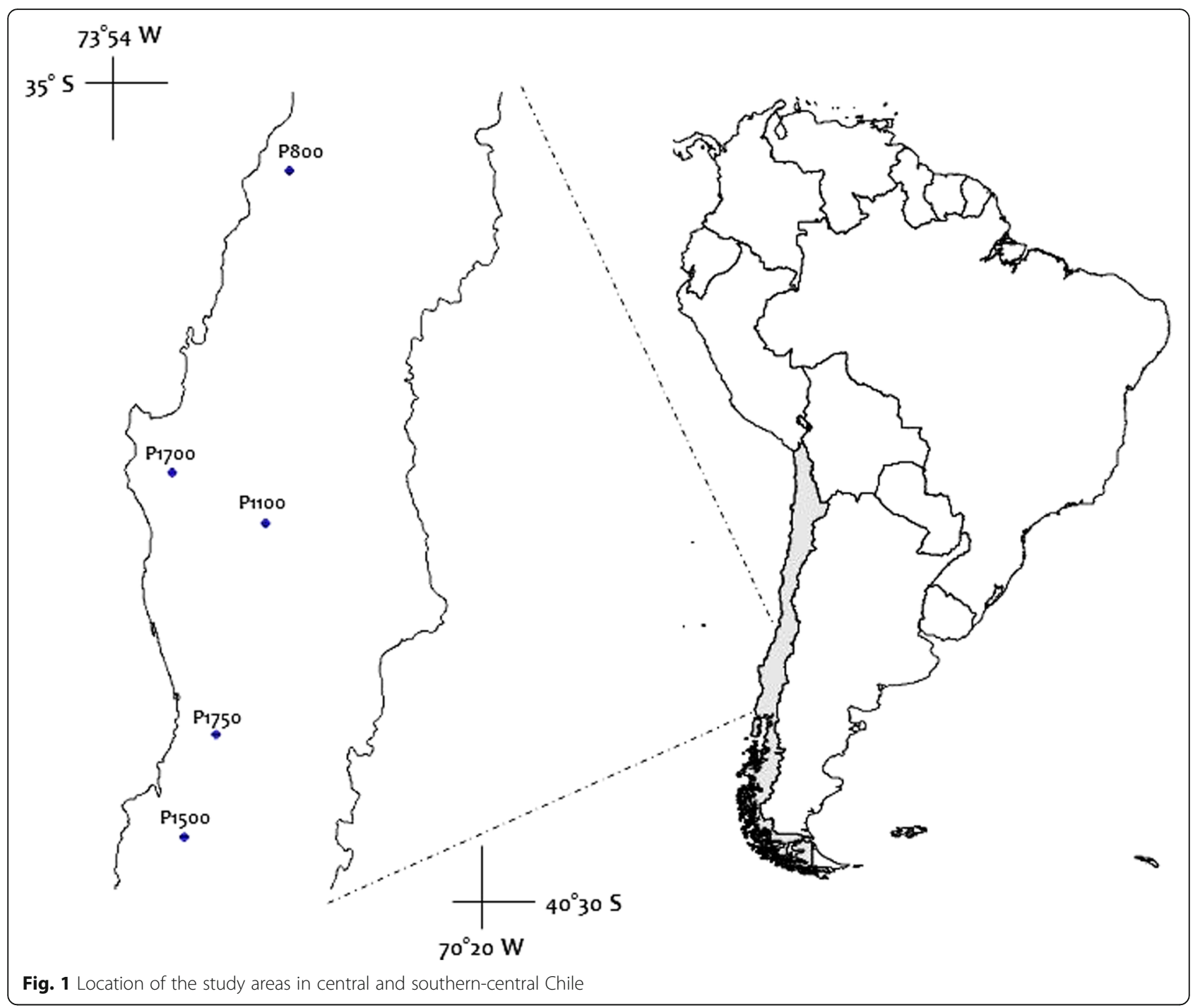

$$
\mathrm{bf}_{i j}=\alpha \times d_{i}^{\left(\beta+b_{j}\right)}+\varepsilon_{i j},
$$

where:

$\mathrm{bf}_{i j}$ is the leaf biomass of the $i$ th tree in site $j(\mathrm{~kg})$

$\alpha, \beta$ are fixed parameters

$d_{i}$ is the diameter of the $i$ th tree $(\mathrm{cm})$

$b_{j}$ is site-specific parameter

$\varepsilon_{i j}$ is the model error

\section{Specific leaf area and leaf area index}

Five trees were selected at each site and 20 fascicles were selected at random and removed from within each vertical third of the tree canopy. Sampled fascicles were refrigerated at $-1{ }^{\circ} \mathrm{C}$ until they were processed. The projected leaf area was estimated using an optical projection system (LI-COR LI-3100C area meter, Li-Cor, Lincoln, NE, EE. UU.). Samples were oven-dried at $70{ }^{\circ} \mathrm{C}$ until constant weight, and the specific leaf area of each was estimated by dividing the projected leaf area by the dry weight. The leaf area of each tree was estimated by multiplying the specific leaf area by the total dry weight of the total foliage of each tree (Eq. 1). Leaf area index (LAI) was then estimated from the total sum of the entire estimated leaf area of all post-thinning remnant trees at the plot, derived from the allometric equation described before, and divided by the total area of the plot. This estimate represents LAI for each stand. Although the optical projection method used could produce some bias compared to the displacement method in the estimation of specific leaf area, the final leaf area values used in this study produced satisfactory relationships across the study sites.

\section{Growth measurements}

The height and diameter of all trees in each plot were measured immediately after thinning, during the 
Table 1 Site and stand characteristics

\begin{tabular}{|c|c|c|c|c|c|}
\hline Site & P800 & P1100 & P1500 & P1700 & P1750 \\
\hline Latitude & $35^{\circ} 29^{\prime} 39^{\prime \prime} \mathrm{S}$ & $37^{\circ} 58^{\prime} 48^{\prime \prime} \mathrm{S}$ & $40^{\circ} 12^{\prime \prime} 2^{\prime \prime S}$ & $37^{\circ} 37^{\prime} 6^{\prime \prime} \mathrm{S}$ & $39^{\circ} 28^{\prime} 22^{\prime \prime} \mathrm{S}$ \\
\hline Longitude & $72^{\circ} 14^{\prime} 8^{\prime \prime} \mathrm{W}$ & $72^{\circ} 26^{\prime} 24^{\prime \prime} \mathrm{W}$ & $73^{\circ} 10^{\prime} 26^{\prime \prime} \mathrm{W}$ & $73^{\circ} 16^{\prime} 40^{\prime \prime} W$ & $72^{\circ} 53^{\prime} 8^{\prime \prime} \mathrm{W}$ \\
\hline Annual mean temperature $\left({ }^{\circ} \mathrm{C}\right)$ & 13.2 & 12.0 & 10.5 & 11.1 & 11.4 \\
\hline Annual mean precipitation (mm) & 833 (25 years) & 1078 (25 years) & 1492 (25 years) & 1683 (25 years) & 1733 (25 years) \\
\hline Geology & Metamorphic & Old volcanic ash & Old volcanic ash & Metamorphic & Recent volcanic ash \\
\hline Soil taxonomy & Typical Rhodoxeralfs & Typical Paleudalfs & Typical Paleudults & Rhodic Paleudults & Typical Haplohumults \\
\hline Texture & Clay & Clay & Clay & Clay & Silt-loam \\
\hline Organic matter (\%) & 1.2 & 3.9 & 6.8 & 4.2 & 11.1 \\
\hline $\mathrm{pH}$ & 5.8 & 5.3 & 5.3 & 5.2 & 5.4 \\
\hline Age (year) & 6 & 6 & 7 & 6 & 6 \\
\hline Stocking before thinning (tree ha-1) & $1250(16)$ & $1093(15)$ & $1156(13)$ & $1074(21)$ & $1022(22)$ \\
\hline Stocking after thinning (tree ha ${ }^{-1}$ ) & $800(0)$ & $800(0)$ & $800(0)$ & $800(0)$ & $800(0)$ \\
\hline Height (m) & $8.7(0.2)$ & $9.5(0.3)$ & $7.9(0.2)$ & $8.6(0.2)$ & $8.3(0.4)$ \\
\hline Diameter (cm) & $10.9(0.2)$ & $13.6(0.8)$ & $15.3(0.3)$ & $14.6(0.2)$ & $13.9(0.4)$ \\
\hline Basal area $\left(\mathrm{m}^{2} \mathrm{ha}^{-1}\right)$ & $7.7(0.3)$ & $11.9(1.3)$ & $15(0.7)$ & $13.6(0.3)$ & $12.6(0.7)$ \\
\hline Volume $\left(\mathrm{m}^{3} \mathrm{ha} \mathrm{a}^{-1}\right)$ & $26.7(1.2)$ & $45(6.3)$ & $47.3(2.6)$ & $46.8(1.7)$ & $44.1(4.1)$ \\
\hline
\end{tabular}

Italicized data in parentheses indicate standard errors

vegetative recess period (June) and 1 year later (period 2007-2008). The increment in diameter growth (IDG) and the increment in height growth (IHG) were calculated as the difference between initial measurements and those after 1 year following thinning. The individual volume of each tree was estimated through a function developed for young radiata pine used by Albaugh et al. (2015), Eq. (3):

$$
\begin{aligned}
V_{i}=(-0.00214 & +0.0000295 \times d_{i}^{2}+0.001349 \\
& \left.\times h_{i}+0.00002486 \times d_{i}^{2} \times h_{i}\right),
\end{aligned}
$$

where:

$V_{i}$ is the volume of the $i$ th tree $\left(\mathrm{m}^{3}\right.$ tree $\left.{ }^{-1}\right)$

$d_{i}$ is the diameter of the $i$ th tree $(\mathrm{cm})$

$h_{i} \quad$ is the height of the $i$ th tree $(\mathrm{cm})$

Individual tree volumes were summed to obtain volume per plot and then scaled at the hectare level. Periodic volume growth (IVG) was calculated by subtracting the estimated volumes between measurement periods (2007-2008).

\section{Climate information}

Daily precipitation and temperature values were obtained from meteorological weather stations located less than $25 \mathrm{~km}$ from each site, belonging to the Chilean Institute of Agricultural Research and the Forestal Arauco S.A. Company. Monthly averages of air temperature and precipitation were calculated as the average of all stations within $25 \mathrm{~km}$ weighted by the inverse of their distance to the site location. Annual precipitation (AP) was calculated from the total sum of the monthly precipitation (August-July). For the estimation of reference evapotranspiration of the sites, the method described by Hargreaves and Samani (1985) was used. Annual water deficit (WD) was calculated as the sum of the monthly deficits (when evapotranspiration is greater than annual precipitation for the study period (Eq. 4)).

$$
\mathrm{WD}=\sum_{i=1}^{n}\left(\mathrm{PP}_{i}-\mathrm{ET}_{0 i}\right) \text {, when }\left|\mathrm{ET}_{0 i}\right|>\left|P P_{i}\right| \text {, }
$$

where:

WD is the water deficit during the year $\left(\mathrm{mm} \mathrm{year}^{-1}\right)$

$\mathrm{PP}_{i}$ is the precipitation of the $i$ th month $\left(\mathrm{mm} \mathrm{month}{ }^{-1}\right)$

$\mathrm{ET}_{0 i}$ is the evapotranspiration of the $i$ th month $\left(\mathrm{mm}\right.$ month $^{-1}$ )

\section{Soil water holding capacity}

Soil water holding capacity (WSC) was estimated through soil pits and soil sampling at each study site. Soil profile was evaluated up to $2 \mathrm{~m}$ depth on each plot. For each horizon, soil thickness was recorded and 400-g samples were obtained for laboratory determination of permanent wilting point (PWP) and field capacity (FC) to estimate soil water retention capacity (Richards 1941). Percentage of stones of each soil horizon was estimated using the point-count method described by Daniels et al. (1968). The soil water holding capacity was defined in Eq. 5 as: 


$$
\mathrm{WSC}=\sum_{i=0}^{n}\left(\mathrm{FC}_{i}-\mathrm{PWP}_{i}\right) \times\left(D_{i} \times\left(1-S_{i}\right)\right),
$$

where:

WSC is the soil water holding capacity $(\mathrm{mm})$

$\mathrm{FC}_{i}$ is the soil water retention capacity at 0.33 bar of the $i$ th horizon (\%)

$\operatorname{PWP}_{i}$ is the soil water retention capacity at 15 bar of the $i$ th horizon (\%)

$D_{i} \quad$ is the soil depth of the $i$ th horizon (mm)

$S_{i} \quad$ is the volumetric percentage of stones of the $i$ th horizon (\%)

\section{Water deficit index}

Water deficit index (WDI) was estimated as the difference between water deficit and soil water holding capacity (Eq. 6):

$$
\text { WDI }=\text { WD-WSC, }
$$

where:

WDI is the water deficit index during the year $\left(\mathrm{mm}\right.$ year $\left.^{-1}\right)$

WD is the water deficit during the year $\left(\mathrm{mm} \mathrm{year}^{-1}\right)$

WSC is the soil water holding capacity $(\mathrm{mm})$

Despite the lower within-site rainfall variation between the four replicates, water storage capacity was calculated using intensive soil sampling within each plot, resulting in a gradient of water deficit index within site.

\section{Statistical analysis}

We adjusted a nonlinear mixed effects model using maximum likelihood for the estimation of leaf biomass of individual trees from diameter at breast height (Eq. 1), depending on the study site (Table 2).

We performed analysis of variance (ANOVA) and multiple comparison test (Tukey) to evaluate differences between sites in LAI, water variables (WDI, WD, and $\mathrm{AP})$, and incremental growth post-thinning variables (IVG, IDG, and IHG). We adjusted simple linear regression models using IVG as the dependent variable and water variables (WDI, WD, and AP) and LAI as independent variables. In addition, we ran regressions using LAI as the dependent variable and water variables (WDI, WD, and AP) as independent variables. The assumptions of the ANOVAS were checked by graphic analysis (independence), Barlett test (homoscedasticity), and Shapiro-Wilk test (normality). Adjusted regression models were diagnosed through graphical and analytical analysis, verifying the assumptions of linearity (graphic analysis), normality (Kolmogorov-Smirnov test), homoscedasticity (Breusch-Pagan test), and residual independence (Durbin-Watson test). Results are reported as significant where $p<0.05$. All analyses were carried out using R software version 3.0.1 (R Core Team 2014).

The relationships between the annual average temperature versus the growth and the leaf area were also explored, but their correlations presented values of $r^{2}$ less than the water deficit; therefore, the water deficit presented a greater force in the determination of the response variable (IVG and LAI).

\section{Results}

\section{Effect of water availability on leaf area}

At the age of 6 years, the average LAI was $1.9 \mathrm{~m}^{2} \mathrm{~m}^{-2}$, with a range of 0.6 to $3.1 \mathrm{~m}^{2} \mathrm{~m}^{-2}$ (Fig. 2). The significant differences between sites are presented in Table 3. The LAI was larger at sites $P 1500$ and $P 1750$ being 3.3 and 3.7 times greater than $P 800$ site respectively. The AP varied between 972 and $1624 \mathrm{~mm}^{\text {year }}{ }^{-1}$ across the study sites. This was associated with a range of 70 and $-751 \mathrm{~mm}$ year $^{-1}$ for the WDI and 285 and $-809 \mathrm{~mm}$ year $^{-1}$ for the WD (Table 3). The site with the most severe water limitation was $P 800$ site, showing the lowest AP and the most negative values for WD and WDI from all the sites. The LAI had a positive linear relationship with AP, WD, and WDI (Fig. 2), showing the strongest correlation with the WDI $(r=0.91)$, followed by the WD $(r=88)$, and finally with AP $(r=0.64)$. Adjusted regression models between LAI and water variables

\begin{tabular}{|c|c|c|c|c|c|}
\hline \multicolumn{6}{|c|}{ Fixed effects } \\
\hline Parameter & Value & Standard error & Degrees of freedom & $t$ value & $p$ value \\
\hline$a$ & 0.0075 & 0.0025 & 44 & 3.0470 & 0.0039 \\
\hline$\beta$ & 2.6328 & 0.1289 & 44 & 20.4229 & 0.0000 \\
\hline \multicolumn{6}{|c|}{ Random effects } \\
\hline Parameter & Site $P 800$ & Site $P 1100$ & Site P1500 & Site $P 1700$ & Site $P 1750$ \\
\hline$b_{j}$ & -0.1674 & 0.0898 & 0.0460 & 0.0640 & -0.0325 \\
\hline \multicolumn{6}{|c|}{ Schwarz's Bayesian criterion } \\
\hline \multicolumn{2}{|c|}{ Akaike information criterion } & \multicolumn{2}{|c|}{ Bayesian information criterion } & Log-likelihood value & $N$ \\
\hline \multicolumn{2}{|l|}{171.3124} & \multicolumn{2}{|l|}{178.9605} & -81.6562 & 50 \\
\hline
\end{tabular}

Table 2 Parameters of the nonlinear model of mixed effects adjusted for maximum likelihood to predict leaf biomass of radiata pine 


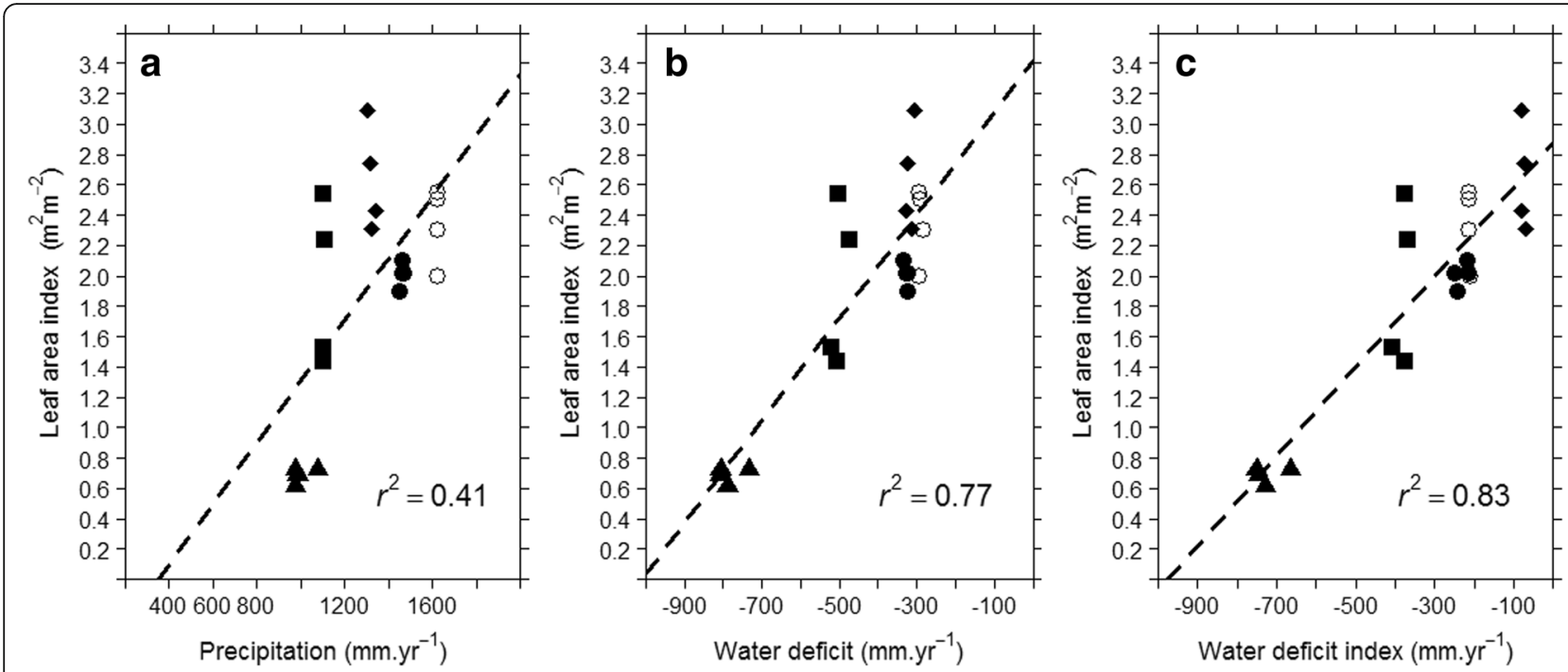

Fig. 2 Relationship between leaf area index and precipitation (a), water deficit (b), and water deficit index (c) for sites P800 (filled triangle), P1100 (filled square), P1500 (open circles), P1700 (filled circles), and P1750 (filled diamond)

(Table 4 ) were highly significant $(p<0.003) ; 83,77$, and $41 \%$ of the variation in LAI could be predicted with WDI, WD, and AP respectively.

\section{Effect of water availability on growth}

The IVG varied between 12.5 and $25.4 \mathrm{~m}^{3} \mathrm{ha}^{-1}$ (Fig. 3), and the volume and diameter growth varied significantly among sites (Table 3). The highest volume and diameter growth was observed at the P1500 site, which showed 86 and $67 \%$ greater growth in volume and diameter respectively than the site with lowest growth (P800). A positive linear relation was found between IVG and WDI, and WD and AP (Fig. 3). The best correlation was with WD $(r=0.89)$, then with
WDI $(r=0.83)$, and finally with AP $(r=0.78)$. Adjusted regression models between IVG and water variables (Table 3 ) were highly significant $(p<0.001)$ and 69,78 , and $60 \%$ of the variation in IVG could be explained by WDI, WD, and AP respectively.

\section{Effect of leaf area on growth}

A positive and strong $(r=0.9)$ linear relation was found between IVG and LAI (Fig. 4). The adjusted regression model between IVG and LAI (Table 4 ) proved to be highly significant $(p<0.001)$ and in addition showed that $81 \%$ of the variation in IVG can be explained by LAI.

Table 3 Averages of leaf area index (LAI), water deficit index (WDI), water deficit (WD), annual precipitation (AP), volume growth (IVG), diameter growth (IDG), and height growth (IHG) for study sites

\begin{tabular}{|c|c|c|c|c|c|c|c|c|c|c|c|c|c|c|}
\hline \multirow{3}{*}{$\begin{array}{l}\text { Site } \\
\text { Mean }\end{array}$} & \multirow{2}{*}{\multicolumn{2}{|c|}{$\frac{\mathrm{LAI}}{\left(\mathrm{m}^{2} \mathrm{~m}^{-2}\right)}$}} & \multirow{2}{*}{\multicolumn{2}{|c|}{$\frac{\text { WDI }}{\left(\mathrm{mm}_{\mathrm{year}}{ }^{-1}\right)}$}} & \multirow{2}{*}{\multicolumn{2}{|c|}{$\frac{\text { WD }}{\left(m m \text { year }^{-1}\right)}$}} & \multirow{2}{*}{\multicolumn{2}{|c|}{$\frac{\mathrm{AP}}{\left(\mathrm{mm} \text { year }^{-1}\right)}$}} & \multirow{2}{*}{\multicolumn{2}{|c|}{$\frac{\text { IVG }}{\left(m^{3} h a^{-1}\right)}$}} & \multirow{2}{*}{\multicolumn{2}{|c|}{$\frac{\mathrm{IDG}}{(\mathrm{cm})}$}} & \multirow{3}{*}{\multicolumn{2}{|c|}{$\frac{\mathrm{IHG}}{(\mathrm{m})}$}} \\
\hline & & & & & & & & & & & & & & \\
\hline & & & & & & & & & & & & & & \\
\hline P800 & 0.7 & $c$ & -723 & $d$ & -784 & $c$ & 1002 & e & 13.1 & $b$ & 1.5 & $c$ & 1.5 & a \\
\hline P1100 & 1.9 & $b$ & -382 & $C$ & -501 & $b$ & 1103 & $d$ & 20.3 & $a$ & 1.9 & bc & 1.4 & a \\
\hline P1500 & 2.3 & $a b$ & -212 & $b$ & -290 & a & 1623 & $\mathrm{a}$ & 24.4 & $\mathrm{a}$ & 2.5 & $\mathrm{a}$ & 1.4 & a \\
\hline P1700 & 2.0 & $a b$ & -231 & $b$ & -326 & a & 1462 & $b$ & 21.5 & $a$ & 2.0 & $b$ & 1.3 & a \\
\hline P1750 & 2.6 & $a$ & -75 & a & -316 & $a$ & 1322 & $c$ & 22.0 & $\mathrm{a}$ & 2.2 & $a b$ & 1.6 & a \\
\hline Standar & rors & & & & & & & & & & & & & \\
\hline P800 & 0.03 & & 19.76 & & 17.56 & & 25.03 & & 0.41 & & 0.08 & & 0.08 & \\
\hline P1100 & 0.27 & & 8.75 & & 9.33 & & 1.53 & & 1.63 & & 0.11 & & 0.01 & \\
\hline P1500 & 0.13 & & 0.60 & & 2.19 & & 0.59 & & 0.39 & & 0.14 & & 0.05 & \\
\hline P1700 & 0.04 & & 9.14 & & 2.17 & & 4.16 & & 1.05 & & 0.08 & & 0.10 & \\
\hline P1750 & 0.17 & & 2.59 & & 4.41 & & 7.24 & & 0.61 & & 0.05 & & 0.04 & \\
\hline
\end{tabular}


Table 4 Linear regression models between leaf area index (LAI), volume growth (IVG) and water variables, water deficit index (WDI), water deficit (WD) and precipitation (AP), in the studied sites

\begin{tabular}{|c|c|c|c|c|c|c|}
\hline Model & $b_{0}$ & $b_{1}$ & $b_{2}$ & Residual standard error & $R$ squared & $p$ value \\
\hline $\mathrm{IVG}=b_{0}+b_{1}{ }^{*} \mathrm{WDI}$ & $25.2894^{*}$ & $0.0155^{*}$ & & 2.42 & 0.69 & $<0.001$ \\
\hline $\mathrm{IVG}=b_{0}+b_{1}^{*} \mathrm{WD}$ & $28.9730^{*}$ & $0.0197^{*}$ & & 2.03 & 0.78 & $<0.001$ \\
\hline $\mathrm{IVG}=b_{0}+b_{1}^{*} \mathrm{AP}$ & 1.9264 & $0.0141^{*}$ & & 2.76 & 0.60 & $<0.001$ \\
\hline IVG $=b_{0}+b_{1}{ }^{*}$ LAI & $10.2873^{*}$ & $5.1907^{*}$ & & 1.90 & 0.81 & $<0.001$ \\
\hline $\mathrm{LAI}=b_{0}+b_{1} * \mathrm{WDI}$ & $2.8767^{*}$ & $0.0029^{*}$ & & 0.31 & 0.83 & $<0.001$ \\
\hline $\mathrm{LAI}=b_{0}+b_{1}{ }^{*} \mathrm{WD}$ & $3.4210^{*}$ & $0.0034^{*}$ & & 0.36 & 0.77 & $<0.001$ \\
\hline $\mathrm{LAI}=b_{0}+b_{1}^{*} \mathrm{AP}$ & -0.7139 & $0.0020^{*}$ & & 0.58 & 0.41 & $<0.003$ \\
\hline
\end{tabular}

*Significance level of the parameter $(p<0.05)$

For the range of sites studied, a growth efficiency (slope of regression line) of $5 \mathrm{~m}^{3} \mathrm{ha}^{-1}$ per LAI unit was found.

\section{Discussion}

\section{Effect of water availability on leaf area}

In this study, LAI directly measured through destructive sampling were made because LAI estimates based on indirect methods can significantly underestimate LAI values. Mason et al. (2012) showed that LAI-2000 underestimated LAI in radiata pine by $60 \%$ for low LAI values and between 30 and $45 \%$ for high LAI values (depending on stocking). Furthermore, they showed that directly measured LAI was less well correlated with LAI estimates from hemispherical images. Breda (2003) also showed that methods based on hemispherical photographs can also suffer from similar underestimation.

Using the strong gradient in soil moisture deficit across sites, we have shown strong relationships between soil water deficit, LAI, and volume increment. Our study confirms previous findings about a positive linear relationship between water availability (WDI, WD, and AP) and LAI (e.g., Grier and Running 1977; Gholz 1982; Battaglia et al. 1998). However, our contribution relies on the simplification of these relationships using a water index that integrates the effects of rainfall, potential evaporation, and available soil water. Alvarez et al. (2013) also used a water index which differs from our WDI because our index gives a greater weight to the lack of water at the site (water deficit).

In our study, correlations between WDI and AP with LAI in radiata pine were greater than those reported by Alvarez et al. (2013) in unthinned stands. We attributed these differences to our lower range of stockings, our smaller climatic annual variability, and the use of destructive sampling to measure LAI instead of using indirect measurements (e.g., LI-COR LAI-2000 or remote sensing). Our observation that an increase in leaf area occurs at sites with little or no water limitations is also supported by the Biology of Forest Growth (BFG) study in Australia. The BFG study, investigating radiata pine under irrigation, showed substantial increases in needle size, and number of needles, and branch growth, which
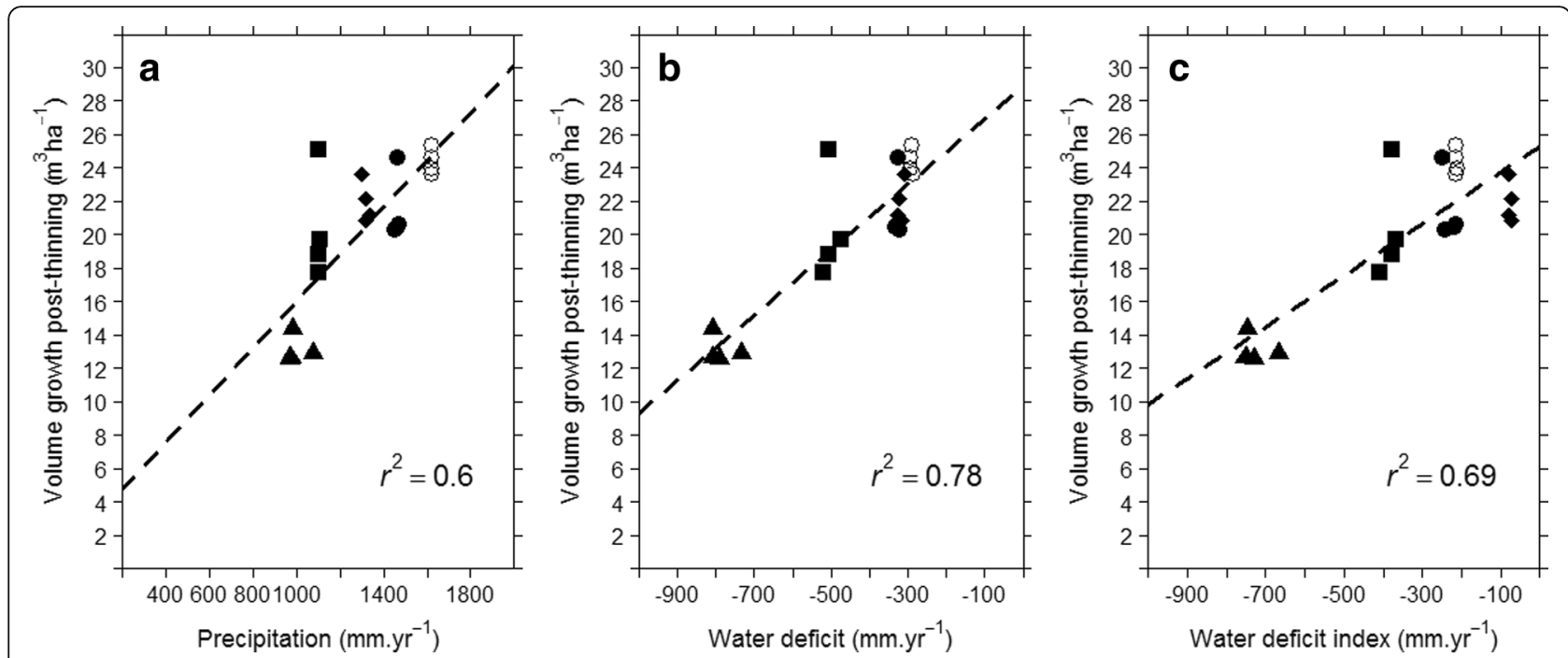

Fig. 3 Relationship between incremental volume growth 1 year post thinning and precipitation (a), water deficit (b), and water deficit index (c) for sites P800 (filled triangles), P1100 (filled squares), P1500 (open circles), P1700 (filled circles), and P1750 (filled diamonds) 


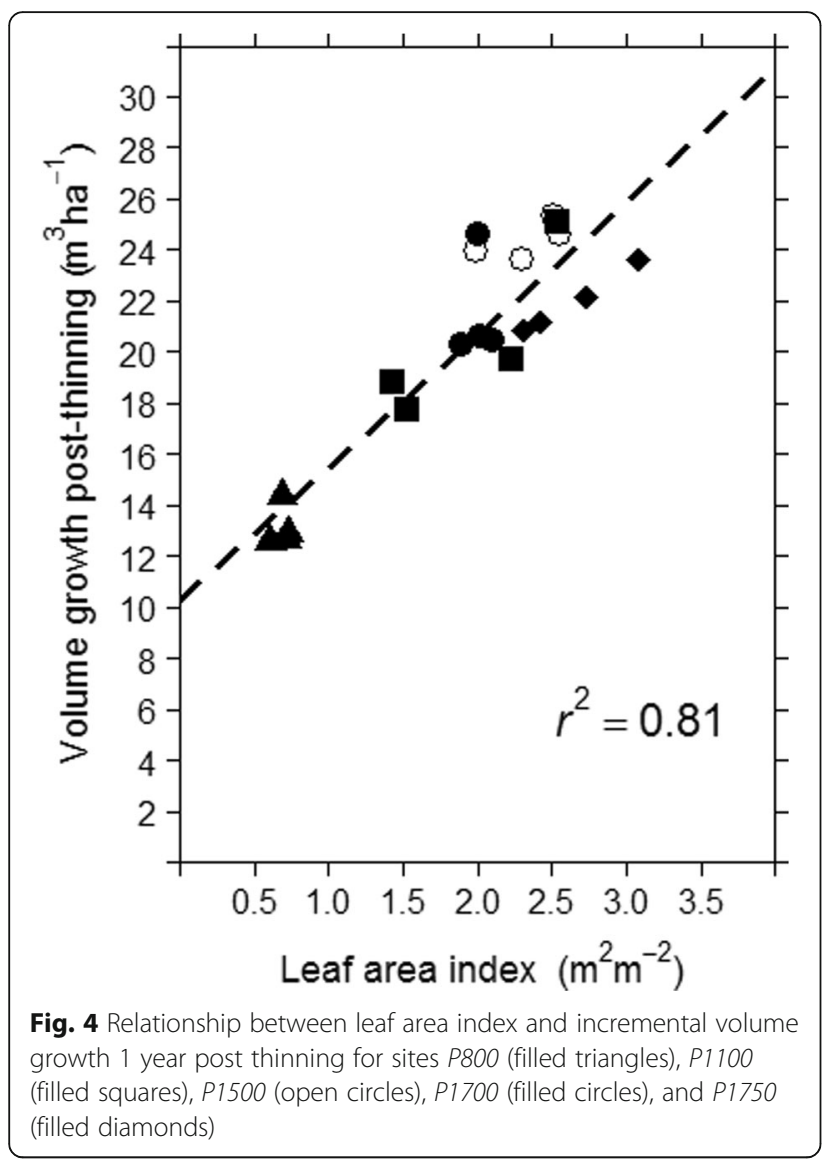

increased stand LAI (Linder et al. 1987; Benson et al. 1992).

Silvicultural treatments can also affect this relationship. For example, Rubilar et al. (2013) reported that LAI increased when weeds were controlled, increasing water availability of the site. In this regard, it is possible that the WDI could act as a surrogate of water competition index accommodating weed competition as well as nitrogen uptake. Variation in water availability is only one of the potential site effects on the leaf area index. LAI can also be affected by nutrition (Linder et al. 1987; Cannell 1989; Raison et al. 1992; Albaugh et al. 1998), light (Gholz 1982), air pollution (Stow et al. 1992), and temperature (Gholz 1986).

The LAI range observed in this study $\left(0.6-3.1 \mathrm{~m}^{2} \mathrm{~m}^{-2}\right)$ is similar to the range reported by Rubilar et al. (2013) $\left(0.51-3.13 \mathrm{~m}^{2} \mathrm{~m}^{-2}\right)$, who also estimated LAI through destructive samples, in 4-year-old radiata pine on contrasting sites in Chile. Alvarez et al. (2013) reported LAI values between 1.2 and $3.7 \mathrm{~m}^{2} \mathrm{~m}^{-2}$ using remote sensing techniques in 11-year-old unthinned radiata pine plantations with an environmental range of sites similar to our study, but the upper limit of their observations was slightly greater than those found in this study. This small difference between the values in our study and those of Alvarez et al. (2013) could be due to sampling age, effect of thinning, or method of LAI estimation.

\section{Effect of water availability on growth}

The level of water stress at any given site, indicated by the WDI, also showed a strong linear and positive relation with IVG. This effect compares well with the one reported by many authors (Jackson and Gifford 1974; Cromer et al. 1983; Hunter and Gibson 1984; Raison and Myers 1992; Benson et al. 1992; Alvarez et al. 2013).

In Chile, Flores and Allen (2004), using the 3-PG-process-based model, evaluated the factors limiting the potential productivity of radiata pine; they also found that the most limiting factor across sites was mean annual rainfall, which is highly consistent with the results of our study. Similar to LAI, IVG showed a stronger relationship with WD or WDI compared to AP models. Nevertheless, the use of AP, a simpler predictor variable as an indirect measure of site water availability, may be highly valuable for developing a model explaining stand growth after thinning across a broad gradient of sites with limited soil information.

Site productivity relationships between IVG and either WDI or AP in our study were stronger than those found by Alvarez et al. (2013) or Gerding and Schlatter (1995) who observed significant relationships between AP and stand site index. Higher correlations observed in this study may be attributed to the use of annual information about both growth and water availability. Highest IVG values were observed in southern and coastal-southern sites, where greater water availability levels were found. This is consistent with Alvarez et al. (2013) and Flores and Allen (2004).

Lack of rainfall during summer in Chile (Mediterranean climate) results in severe water limitations for tree growth even on wetter sites; this is especially relevant in northern regions where radiata pine is planted. Greater growth values for radiata pine can be found in stands located in the foothills of the Andes and the southern coast where water deficit value is low.

Both WD and WDI take into account the annual seasonal water availability (rainfall and evapotranspiration) allowing a better understanding of growth differences between radiata pine plantations growing at sites with contrasting water regimes such as Chile, South Africa, Australia, and New Zealand. Although an index that takes into account leaf area considering seasonal transpiration could be more precise, the greater inference is given by the large water differences between sites, which allows us to explore that the WDI could be considered independent of the leaf area. Our intention is to use a simple index that would allow practitioners in forest biometrics to add water balance components in an easy way to serve as an applied tool by being a proxy from the current water balance. 
Therefore, given the wide water gradient between sites, our water deficit index proxy for a more complete water balance sufficed the purpose.

Undoubtedly, other factors will affect the LAI or growth response. In addition to water stress, other authors (Jackson and Gifford 1974; Hunter and Gibson 1984; Gerding and Schlatter 1995; Watt et al. 2010; Alvarez et al. 2013) have concluded that the variability found in growth is not only influenced by other climate variables, such as maximum average growing season temperature and vapor pressure deficit, but also by soil variables such as organic soil carbon, organic matter, and soil water holding capacity. Mean annual temperature, closely related to vapor pressure deficit, strongly influences evapotranspiration in Chile and both variables decrease with latitude contrasting with precipitation, which increases with latitude. Given the above, it can be argued concordance with the exposed by Alvarez et al. (2013), who suggested temperature and vapor pressure deficit as the variables that mostly explain the growth of radiata pine plantations in Chile, also mean annual rainfall can be considered as a strong predictor alone.

\section{Effect of leaf area on growth}

The strong linear relationship between LAI and IVG is consistent with the observation that both LAI and IVG are well correlated with water availability. Interestingly, although stands in this study were thinned at or near canopy closure decreasing their maximum leaf area and our study only consider records for one single growing period, the observed relationship is similar to unthinned radiata pine stands reported in Australia, New Zealand, and Chile (Linder et al. 1987; Beets and Pollock 1987; Raison and Myers 1992; Alvarez et al. 2013; Rubilar et al. 2013) and also for unthinned Pinus taeda L. (Albaugh et al. 1998).

The adjusted regression model to estimate IVG from LAI (Table 3) showed a good fit $\left(r^{2}=0.81\right)$ similar to that reported by Rubilar et al. (2013) $\left(r^{2}>0.8\right)$ and above the one shown by Alvarez et al. (2013) $\left(r^{2}=0.46\right)$. However, it should be noted that for a Mediterranean climate and within the water gradient of sites presented in this research, the leaf area is directly related to water stress.

Similar relationships have also been shown in the literature by process-based models considering the impact of site water availability on leaf area production and its efficiency in growth. It should be noted that the leaf area could not only be affected by the water condition of the site, but also by other variables such as soil characteristics (nutritional, extreme textures) or other climatic variables (vapor pressure deficit, temperature) and biotic agents.

The slope of the linear relationship between LAI and IVG, growth efficiency, represents the efficiency of captured light and its conversion into annual stand growth (current annual increment or CAI) per unit of leaf area.
Results of our study show a slope of $5.2 \mathrm{~m}^{3} \mathrm{ha}^{-1}$ per unit of LAI, which is within the range reported by Rubilar et al. (2013) for younger unthinned stands and under the mean value reported by Alvarez et al. (2013) for older unthinned stands showing larger growth rates. Changes in the slope between LAI and CAI indicate differences in growth efficiency (GE) among stands. Increases in water and nutrient availability have shown increases in GE for radiata pine (Linder et al. 1987; Raison and Myers 1992). Rubilar et al. (2013) presented large differences in GE in radiata pine between low fertility dry sands and medium fertility red clay sites sustaining similar leaf area levels for younger stands. Sites in our study did not show nutritional limitations or low fertilities that affect growing trees, although the water gradient of the sites could have an impact on nutrients uptake. However, and despite the large water gradient considered in our study, we were not able to observe differences in GE among stands.

Although the focus of the research was on the water gradient of the sites, it should be noted that the soil types affect the water availability and hence leaf area and tree growth. Among the soil characteristics that can affect water availability and productivity, Gerding and Schlatter (1995) highlight the negative effect of sandy textures and high bulk density and the positive effect of a higher soil water holding capacity, higher total volume of pores, and higher content of organic matter. The types of soil present in this study, varied from metamorphic to volcanic ashes, showing mostly clay soil texture, the biggest differences that could affect water availability between the sites, were related to the levels of organic matter, depth, and soil water holding capacity. Metamorphic soils especially with low rainfall showed the lowest values of organic matter and soil water holding capacity; in addition, the metamorphic soils showed to be the least deep; on the other hand, the soils of recent volcanic ash showed the highest values of organic matter and soil water holding capacity.

Declines in spring-summer rainfall are expected in areas where radiata pine is planted due to climate change in Chile (Galindo and Samaniego 2010). Our results suggest that reductions in site water availability may be expected to cause reductions in leaf area of radiata pine plantations, which will cause significant productivity declines. A large challenge for foresters is to implement thinning regime and better genetic materials that may be more effective at utilizing water resources as the most limiting factor underpinning forest productivity.

\section{Conclusions}

Strong linear positive relationships among site water availability, leaf area, and stand growth after thinning 
suggest that water availability plays an important role on predicting current productivity of radiata pine plantations across sites.

A simple and robust water index, which integrates the effects of rainfall, potential evaporation, and available soil water, is well correlated with leaf area and stand annual volume growth. This index allows the construction of a simple predictive model that may support management decisions for radiata pine plantations.

The results of our study provide useful information for forest managers to estimate stand growth after thinning of radiata pine plantations under an expected climate change scenario with reductions in site water availability for radiata pine plantations in Chile.

Further research should be carried out to establish relationships between site water availability and growth responses to other plantation management activities such as stocking or pruning where the leaf area is also modified.

\section{Abbreviations}

ANOVA: Analysis of variance; AP: Annual precipitation; BFG: Biology of Forest Growth; CAl: Current annual increment; DBH: Diameter at breast height; GE: Growth efficiency; IDG: Diameter growth; IHG: Height growth;

IVG: Volume growth; LAl: Leaf area index; WD: Annual water deficit; WDI: Water deficit index; WSC: Soil water storage capacity

\section{Acknowledgements}

We are grateful to Bioforest SA (Forestal Arauco) for sharing study information, logistic, and financial support to this study. We also acknowledge the support of the Forest Productivity Cooperative (FPC) at Universidad de Concepción (Chile) and the Plantation Management Research Cooperative (PMRC) at University of Georgia (USA) for laboratory space and equipment for data analysis.

\section{Funding}

We acknowledge the generous funding from Bioforest S.A. (Forestal Arauco) for the complete realization of this research and Universidad de Concepción and MECESUP program (Project Code UCO14-10) for funding Mr. Hebert Ojeda's internship at University of Georgia.

\section{Availability of data and materials}

The data belongs in full to Forestal Arauco S.A., and the results of this publication were authorized as a part of a $\mathrm{PhD}$ thesis project developed by Mr. Hebert Ojeda at Universidad de Concepción. Any request to use the original data for publication purposes requires a specific project proposal to be approved by the company for any interested scientist in making use of the datasets.

\section{Authors' contributions}

$\mathrm{HO}$ was the primary author, undertook the analyses, and supervised the field measurements. RR and CM contributed with the analyses and interpretation of data, and JC and ME provided critical revisions of the manuscript. All authors read and approved the final manuscript.

\section{Authors' information}

$\mathrm{HO}$ is a researcher and Forest Management Program Leader of Bioforest, Forestal Arauco, Chile. He is a graduate of the Forest Sciences Ph.D. Graduate Program, Department of Forestry, Faculty of Forestry Sciences, University of Concepción, Chile.

RR Ph.D. is an Associate Professor in Soils, Nutrition and Sustainable Forest Productivity and the Co-Director in Forest Productivity Cooperative, Department of Forestry, Faculty of Forestry Sciences, University of Concepción, Chile. CM Ph.D. is an Associate Professor of Natural Resource Biometrics and Timber Management and the Co-Director of Plantation Management
Research Cooperative, Warnell School of Forestry and Natural Resources, University of Georgia, EE. UU.

JC Ph.D. is the Dean and Full Professor of Biometrics, Faculty of Forestry Sciences, University of Concepción, Chile.

ME Ph.D. is the Emeritus Professor of Silviculture, Department of Forestry, Faculty of Forestry Sciences, University of Concepción, Chile.

Ethics approval and consent to participate

Not applicable for this section

\section{Consent for publication}

Not applicable for this section.

\section{Competing interests}

The authors declare that they have no competing interests.

\section{Publisher's Note}

Springer Nature remains neutral with regard to jurisdictional claims in published maps and institutional affiliations.

\section{Author details}

${ }^{1}$ Facultad de Ciencias Forestales, Universidad de Concepción, Victoria 631, Barrio Universitario, Concepción, Chile. ${ }^{2}$ Bioforest S.A., Camino a Coronel km $15 \mathrm{~s} / \mathrm{n}$, Coronel, Chile. ${ }^{3}$ Warnell School of Forestry and Natural Resources, University of Georgia, 180 E Green Street, EE.UU "Athens, Georgia.

Received: 5 July 2017 Accepted: 14 June 2018

Published online: 09 July 2018

\section{References}

Albaugh, TJ, Allen, HL, Dougherty, PM, Kress, LW, King, JS. (1998). Leaf area and above-and belowground growth responses of loblolly pine to nutrient and water additions. Forest Science, 44(2), 317-328.

Albaugh, TJ, Alvarez, J, Rubilar, RA, Fox, TR, Allen, HL, Stape, JL, Mardones, O. (2015). Long-term Pinus radiata productivity gains from tillage, vegetation control, and fertilization. Forest Science, 61(4), 800-808.

Álvarez, J, Allen, HL, Albaugh, TJ, Stape, JL, Bullock, BP, Song, C. (2013). Factors influencing the growth of radiata pine plantations in Chile. Forestry, 86(1), 13-26.

Battaglia, M, Cherry, ML, Beadle, CL, Sands, PJ, Hingston, A. (1998). Prediction of leaf area index in eucalypt plantations: effects of water stress and temperature. Tree Physiology, 18(8-9), 521-528.

Beets, PN, \& Pollock, DS. (1987). Accumulation and partitioning of dry matter in Pinus radiata as related to stand age and thinning. New Zealand Journal of Forestry Science, 17(2), 246-271.

Benecke, U. (1980). Photosynthesis and transpiration of Pinus radiata D. Don under natural conditions in a forest stand. Oecologia, 44(2), 192-198.

Benson, ML, Myers, BJ, Raison, RJ. (1992). Dynamics of stem growth of Pinus radiata as affected by water and nitrogen supply. Forest Ecology and Management, 52(1-4), 117-137.

Breda, NJ. (2003). Ground-based measurements of leaf area index: a review of methods, instruments and current controversies. Journal of Experimental Botany, 54(392), 2403-2417.

Cannell, MGR. (1989). Physiological basis of wood production: a review. Scandinavian Journal of Forest Research, 4(1-4), 459-490.

Cromer, RN, Tompkins, D, Barr, NJ (1983). Irrigation of Pinus radiata with waste water: tree growth in response to treatment. Australian Forest Research, 13(1), $57-65$.

Czarnowski, MS, Humpreys, FR, Gentle, SW (1971). Quantitative expression of siteindex in terms of certain soil and climate characteristics of Pinus radiata D. Don. Oddział: Plantations in Australia and New Zealand. Państwowe Wydawnictwo Naukowe.

Daniels, RB, Gamble, EE, Bartelli, L, Nelson, LA. (1968). Application of the pointcount method to problems of soil morphology. Soil Science, 106(2), 149-152.

Del Lungo, J, \& Carle, J (2006). Global planted forests thematic study: results and analysis. [Working Paper FP/38]. Rome: Forestry Department, Food and Agriculture Organization of the United Nations.

Flores, FJ, \& Allen, H. (2004). Efectos del clima y capacidad de almacenamiento de agua del suelo en la productividad de rodales de pino radiata en Chile: un análisis utilizando el modelo 3-PG. Bosque (Valdivia), 25(3), 11-24. 
Galindo, LM, \& Samaniego, J (2010). La economía del cambio climático en América Latina y el Caribe: algunos hechos estilizados. Revista Cepal.

Gerding, V, \& Schlatter, JE (1995). Variables y factores del sitio de importancia para la productividad de Pinus radiata D. Don en Chile. Bosque, 16(2), 39-56.

Gholz, HL. (1982). Environmental limits on aboveground net primary production, leaf area, and biomass in vegetation zones of the Pacific Northwest. Ecology, 63(2), 469-481.

Gholz, HL (1986). Canopy development and dynamics in relation to primary production, (pp. 224-242). Ibaraki, Japan: Crown and Canopy Structure in Relation to Productivity. Forestry Products Research Institute.

Gower, ST, Vogt, KA, Grier, CC. (1992). Carbon dynamics of Rocky Mountain Douglas-fir: influence of water and nutrient availability. Ecological Monographs, 62(1), 43-65.

Grey, DC. (1989). Site requirements of Pinus radiata: a review. South African Forestry Journal, 148(1), 23-27.

Grier, CG, \& Running, SW. (1977). Leaf area of mature northwestern coniferous forests: relation to site water balance. Ecology, 58(4), 893-899.

Guo, LB, \& Gifford, RM. (2002). Soil carbon stocks and land use change: a meta analysis. Global Change Biology, 8(4), 345-360

Hargreaves, GH, \& Samani, ZA. (1985). Reference crop evapotranspiration from temperature. Applied Engineering in Agriculture, 1(2), 96-99.

Hunter, IR, \& Gibson, AR. (1984). Predicting Pinus radiata site index from environmental variables. New Zealand Journal of Forestry Science, 14(1), 53-64.

Jackson, DS, \& Gifford, HH. (1974). Environmental variables influencing the increment of radiata pine (1) periodic volume increment. New Zealand Journal of Forestry Science, 4, 3-26.

Jarvis, PG, \& Leverenz, JW (1983). Productivity of temperate, deciduous and evergreen forests. In Physiological plant ecology IV (pp. 233-280). Berlin: Springer.

Kirschbaum, MU, Watt, MS, Tait, A, Ausseil, AGE. (2012). Future wood productivity of Pinus radiata in New Zealand under expected climatic changes. Global Change Biology, 18(4), 1342-1356.

Linder, S. (1987). Responses to water and nutrients in coniferous ecosystems (pp. 180-202). Springer-Verlag, Berlin.

Linder, S, Benson, ML, Myers, BJ, Raison, RJ (1987). Canopy dynamics and growth of Pinus radiata I. Effects of irrigation and fertilization during a drought. Canadian Journal of Forest Research, 17(10), 1157-1165.

Mason, EG, Diepstraten, M, Pinjuv, GL, Lasserre, JP (2012). Comparison of direct and indirect leaf area index measurements of Pinus radiata D. Don. Agricultural and Forest Meteorology, 166, 113-119.

Mead, DJ (2013). Sustainable management of Pinus radiata plantations. Food and Agriculture Organization of the United Nations (FAO). Rome: Food and Agriculture Organization of the United Nations.

Ministry for Primary Industries, New Zealand Forest Owners Association Inc. \& New Zealand Farm Forestry Association (2016). Forest description as at 1 April 2016. [Resource document]. https://www.nzfoa.org.nz/images/stories/ pdfs/2016-NEFD-report_web.pdf. Accessed 09 October 2017.

Mullan, B., Porteous, A., Wratt, D., \& Hollis, M. (2005). Changes in drought risk with climate change. Prepared for Ministry for the Environment (NZ Climate Change Office) and Ministry of Agriculture and Forestry. NIWA Client Report: WLG200523. (National Institute of Water and Atmospheric Research, Wellington).

Neuenschwander, A (2010). El cambio climático en el sector silvoagropecuario de Chile. Fundación para la Innovación Agraria (FIA). Santiago.

R Core Team. (2014). R: a language and environment for statistical computing. $R$ Foundation for Statistical Computing. http://www.R-project.org/.

Raison, RJ, \& Myers, BJ. (1992). The biology of forest growth experiment: linking water and nitrogen availability to the growth of Pinus radiata. Forest Ecology and Management, 52(1-4), 279-308.

Raison, RJ, Myers, BJ, Benson, ML. (1992). Dynamics of Pinus radiata foliage in relation to water and nitrogen stress: I. Needle production and properties. Forest Ecology and Management, 52(1-4), 139-158.

Richards, LA. (1941). A pressure-membrane extraction apparatus for soil solution. Soil Science, 51(5), 377-386.

Rubilar, RA, Albaugh, TJ, Allen, HL, Alvarez, J, Fox, TR, Stape, JL. (2013). Influences of silvicultural manipulations on above-and belowground biomass accumulations and leaf area in young Pinus radiata plantations, at three contrasting sites in Chile. Forestry, 86(1), 27-38.

Rubilar, RA, Allen, HL, Alvarez, JS, Albaugh, TJ, Fox, TR, Stape, JL (2010). Silvicultural manipulation and site effect on above and belowground biomass equations for young Pinus radiata. Biomass and Bioenergy, 34(12), 1825-1837.
Stow, TK, Allen, HL, Kress, LW. (1992). Ozone impacts on seasonal foliage dynamics of young loblolly pine. Forest Science, 38(1), 102-119.

Vose, JM, \& Allen, HL. (1988). Leaf area, stemwood growth, and nutrition relationships in loblolly pine. Forest Science, 34(3), 547-563.

Vose, JM, Dougherty, PM, Long, JN, Smith, FW, Gholz, HL, Curran, PJ (1994). Factors influencing the amount and distribution of leaf area of pine stands. Ecological Bulletins, 43, 102-114.

Watt, MS, Palmer, DJ, Kimberley, MO, Höck, BK, Payn, TW, Lowe, DJ. (2010). Development of models to predict Pinus radiata productivity throughout New Zealand. Canadian Journal of Forest Research, 40(3), 488-499.

White, DA, Battaglia, M, Mendham, DS, Crombie, DS, Kinal, J, McGrath, JF. (2010). Observed and modelled leaf area index in Eucalyptus globulus plantations: tests of optimality and equilibrium hypotheses. Tree Physiology, 30(7), 831-844.

\section{Submit your manuscript to a SpringerOpen ${ }^{\circ}$ journal and benefit from:}

- Convenient online submission

- Rigorous peer review

- Open access: articles freely available online

- High visibility within the field

- Retaining the copyright to your article

Submit your next manuscript at springeropen.com 